\title{
CYANOBACTERIA TOXINS: DIVERSITY AND ECOLOGICAL EFFECTS
}

\author{
V. Vasconcelos
}

Departamento de Zoologia e Antropologia - Faculdade de Ciências - Praça Gomes Teixeira - 4050 Porto Portugal and CIIMAR-Centro Interdisciplinar de Investigação do Mar e Ambiental - R. do Campo Alegre 4000 Porto - Portugal

\begin{abstract}
Cyanobacteria are known to produce secondary metabolites which are toxic to mammals, commonly known as "toxins". These have been described as having neurotoxic, hepatotoxic and dermatotoxic effects, being a hazard also to humans. Cyanobacteria blooms may represent a hazard to aquatic organisms, when cells collapse, releasing cyanotoxins to the water. Toxins, though, have a dramatic influence on many groups of other arganisms. Zooplankton species are affected by cyanotoxins Daphnia is used as a test organism for cyanobacteria toxicity evaluation. Rotifers and small cladocerans seem to be less sensitive to cyanobacteria toxicity. This partly explains the dominance of small zooplankton groups during cyanobacteria blooms. Molluscs such as mussels are also little affected by cyanobacteria toxins, being able to transfer them along food chains up to humans. Mussels purify microcystins from their body slowly, making them good toxin vectors. Larger crustaceans such as crayfish may be also considered as toxin vectors, having low toxin sensitivity even during early larval phases. The response of fish to toxins is quite diverse and is related to food habit. Carp seem to accumulate more toxins than mullet or barb and they are not much affected by oral toxicity. Many of these animals may act as vectors for toxins better than other more sensitive organisms, which may be badly affected by the toxins.
\end{abstract}

Key words: Cianobacteria, cyanotoxins, microcystin, toxin vectors, zooplankton, moluscs, fishes.

\section{RESUMEN}

Es bien sabido que las cianobacterias producen metabolitos secundarios con efectos toxicos sobre los mamiferos y que se conocen como toxinas. Estas han sido descritas por sus efectos neurotóxicos, hepatotoxicos y dermatotóxicos siendo un riesgo también para los seres humanos. Aunque las floraciones de cianobacterias pueden representar un riesgo para los organismos acuáticos, principalmente cuando mueren y lisan, las cianotoxinas liberadas al agua tienen un efecto dramático en muchos otros grupos de organismos. Las especies del zoopláncton son afectadas por las cianotoxinas y por este motivo se puede usar a Daphnia como un organismo útil para los tests de evaluación de toxicidad de las cianobacterias. Los Rotíferos y pequeños cladoceros parecen ser menos sensibles a la toxicidad de las cianobacterias siendo este unos de los factores que llevan a una dominancia de estos grupos durante las floraciones. Los moluscos del grupo de los bivalvos (mejillones) también parecen ser poco afectados por las toxinas de las cianobacterias, aunque son capaces de transferirlas a través de las cadenas troficas hacia los humanos. El proceso de depuracion de las microcistinas por parte de los mejillones es bastante lento y esto les permite ser buenos vectores para la toxina. Los grandes crustáceos como los cangrejos pueden ser también considerados como vectores tóxicos con baja sensibilidad para la toxina incluso durante las fases larvales. La respuesta de los peces a las toxinas es bastante diversa y se relaciona con sus habitos alimentarios. Las carpas parecen acumular mas toxinas que los mujoles o los barbos, que no resultan muy afectados por la toxicidad via oral. Muchos de estos animales pueden actuar mejor como vectores de las toxinas que otras especies que pueden resultar afectadas por ellas.

Palabras clave: Cianobacterias, cianotoxinas, microcistinas, vectores de toxicidad, zooplancton, moluscos, peces. 


\section{CYANOBACTERIA AND THEIR TOXINS}

\section{Toxic cyanobacteria}

Freshwater cyanobacteria are known to produce secondary metabolites with toxic properties to mammals but also to aquatic invertebrates. The first report on the occurrence of toxic cyanobacteria is from a livestock intoxication in Australia in the 19th century (Francis, 1878).At that time, sheep were found dead and the cause was found to be toxic cyanobacteria ingested by them from water of a eutrophic lake. Since this report was published many others have shown that toxic cyanobacteria can also intoxicate mammals, waterfowl and fish (Bossenmaier et al., 1954, Davidson, 1959, Sawyer et al., 1968).

Humans are also found to be intoxicated by cyanobacteria, either due to accidental ingestion of water during, for example, aquatic sports or following ingestion of drinking water contaminated with toxic cyanobacteria (Falconer et al., 1983, Turner et al., 1990). The recent episode of a fatal human intoxication in Caruaru, Brazil, due to the treatment of kidney failure by dialysis with water contaminated with cyanobacterial toxins (Jochimsen et al., 1998), led us to look at cyanobacteria in more detail. The most common cyanobacteria genera associated with toxicity are Anabaena, Microcystis, Aphanizomenon, Oscillatoria, Nodularia and Cylindrospermopsis.
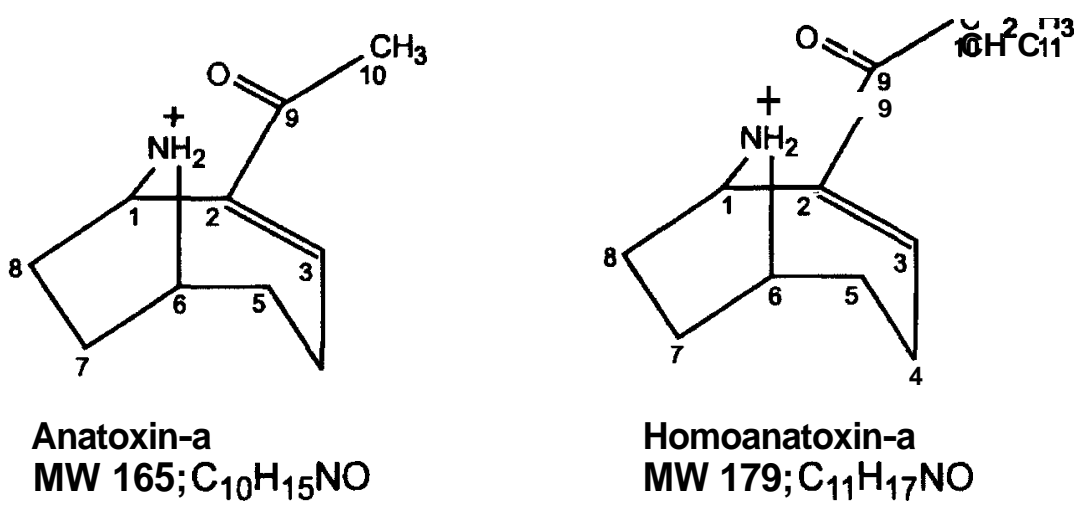

Homoanatoxin-a MW $179 ; \mathrm{C}_{11} \mathrm{H}_{17} \mathrm{NO}$<smiles>COP(=O)(OC)ON1C(=[NH2+])NC[C@H]1CN(C)C</smiles>

Anatoxin-a(S) MW 252; $\mathrm{C}_{7} \mathrm{H}_{17} \mathrm{~N}_{4} \mathrm{O}_{4} P$

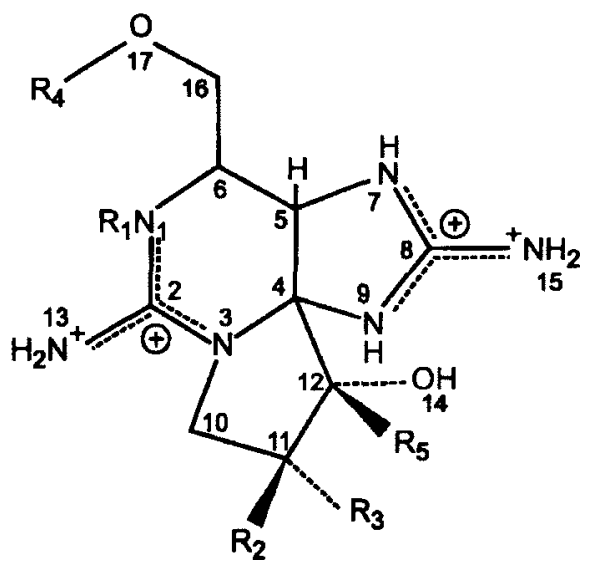

General structure of saxitoxins

Figure 1. Structure of the most common neurotoxins produced by cyanobacteria (in Sivonen and Jones, 1999). Estructura de las neurotoxinas más comunes producidas por las cinnohacterias (en Sivonen and Jones, 1999). 


\section{Cyanobacteria toxins}

Cyanobacteria toxins may be divided into three groups according to their effects on mammals: irritants, neurotoxins and hepatotoxins.

Irritants are the toxins that may be considered the least harmful to humans, with the exception made of toxins produced by Lyngbya majuscula in tropical waters, as these may cause severe dermatitis and are tumour promoters (Moikeha \& Chu, 1971).

Neurotoxins compose a group of toxins with a diverse chemical composition, although they produce similar symptoms, examples are anatoxin-a, anatoxin-a(s), saxitoxins and neosaxitoxins (Fig. 1). All neurotoxins produce rapid lethal intoxications in mice injected with high doses. Animals may die in a few minutes. The biochemical effects and the chemical structure differ among the three major groups. While anatoxin-a is an alkaloid, anatoxin-a(s) is a natural organophosphate. Indeed, it is the only naturally produced organophosphate known of to date. Saxitoxins are alkaloids that may vary in their composition according to changes in radicals (Sivonen \& Jones, 1999).

Saxitoxins produce the blockage of sodium ion channels leading to the inhibition of impulse generation in peripheral nerves and skeletal muscles. Animals die of respiratory arrest (KuiperGoodman et al., 1999).

Anatoxin-a mimics acetylcholine and it binds to muscle acetylcholine receptors inducing contraction of the muscle. As it is not degraded by acetilcholinesterase, the molecules of the toxin continuously stimulate the muscle until paralysis occurs (Kuiper-Goodman et al., 1999).

Anatoxin-a(s) is an acetylcholinesterase inhibitor. The acetylcholine molecules are thus not degraded and can continuously stimulate the muscle, leading to paralysis. Animal death occurs after respiratory arrest and they present intensive salivation (Kuiper-Goodman et al., 1999).

On the other hand, hepatotoxins cause death in animals either by liver failure or by hypovolemic shock. A group of these toxins, the cylindrospermopsins, may also cause kidney damage.
Hepatotoxins may be divided in three groups: microcystins, nodularins and cylindrospermopsins, a according to their chemical structure. The first two groups are peptides while cylindrospermopsins are alkaloids.

Microcystins are cyclic heptapeptides (Fig. 2) composed of common aminoacids such as alanine, arginine, tryptophane, leucine and of a special amino acid only found in these toxins and in nodularins called ADDA. ADDA is a (2S,3S, 8S, 9S )-3-amino-9-methoxy-2,6,8trimethyl-10-phenyldeca-4,6-dienoic acid, and it is the structure responsible for the toxic properties of microcystins and nodularins. Changes may occur in some of the variable amino acids and also some chemical transformations (methylations, etc.), leading to the occurrence of more than 60 variants of microcystins found until now.

Nodularins have a structure similar to that of microcystins except for the number of amino acids (Fig. 2). Nodularins are composed of five amino acids, being ADDA one of them. There is some variation in aminoacid composition among nodularins, although not as large as that in microcystins.

Microcystins and nodularins cause severe disruptions of liver structure. They inhibit eukariotic protein phosphatases 1 and 2A (Mackintosh et al., 1990, Runnegar et al., 1993). This property is responsible for the tumour-promoting activity of these toxins (Fujiki \& Suganuma, 1993). They are not very lipophylic and can enter hepatocytes via the bile acid transport system. Once inside these cells they are responsible for the disruption of the cytoskeleton. Cells shrink, leading to haemorrhage of the liver. Blood will progressively fill gaps between cells leading to intra-hepatic haemorrhage and to death by hypovolemic shock (Falconer \& Yeung, 1993).

Cylindrospermopsins are alkaloids produced by Cylindrospermopsis, Umezakia or Aphanizomenon (Sivonen \& Jones, 1998). This toxin induces pathological changes in the liver but also in kidneys, spleen, thymus and heart (Hawkins et al., 1985, 1997). In vitro studies show that they inhibit glutathione synthesis and protein synthesis (Runnegar et al., 1994, Terao et al., 1994). 
A

(5)

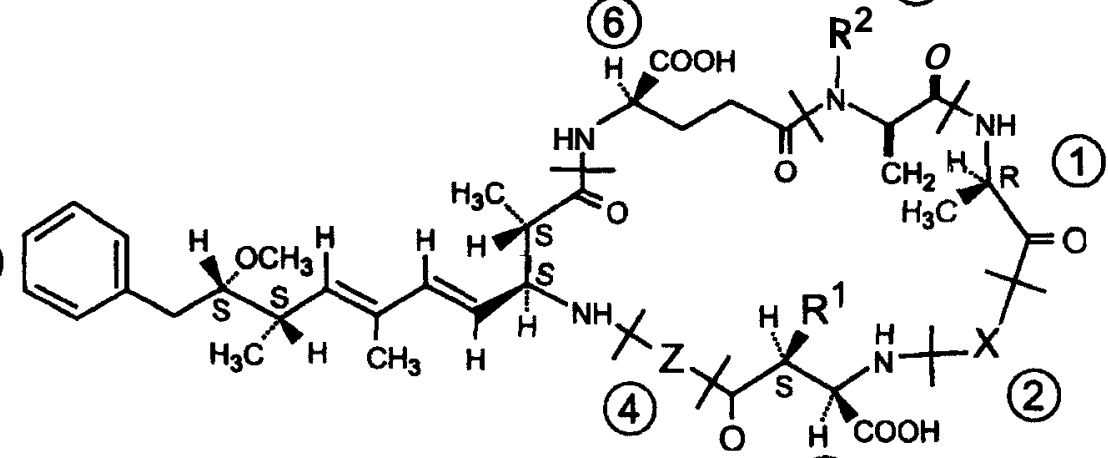

General structure of microcystins

(3)

cyclo-(D-Ala ${ }^{1}-\mathrm{X}^{2}-\mathrm{D}-\mathrm{MeAsp}{ }^{3}-Z^{4}-\mathrm{Adda}^{5}-\mathrm{D}-\mathrm{Glu}^{6}-\mathrm{Mdha}^{7}$ )

B

(3)

(4)

(7)

(6)

(4)

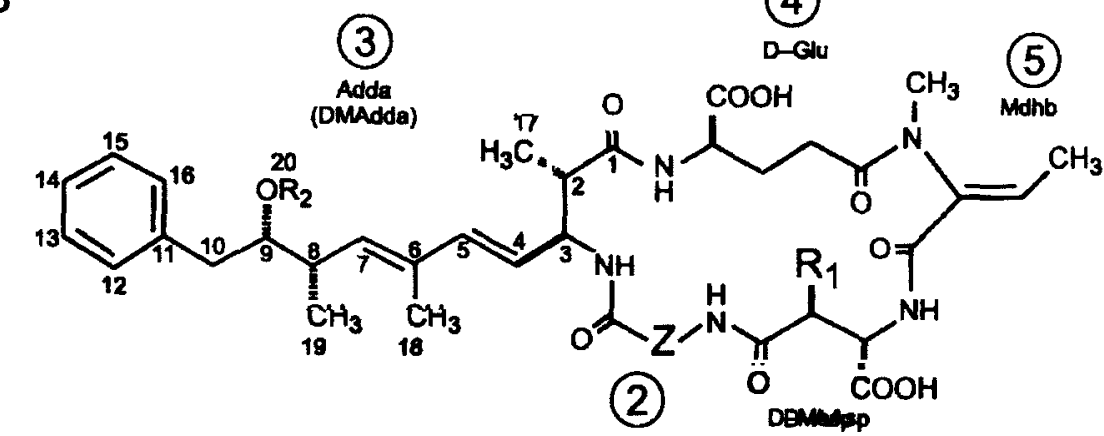

\section{Structure of nodularins}

cyclo-(D-MeAsp ${ }^{4}-Z^{2}-A d d a^{3}-D-G l{ }^{4}-M d h b^{5}$ )

C

Cylindrospermopsin

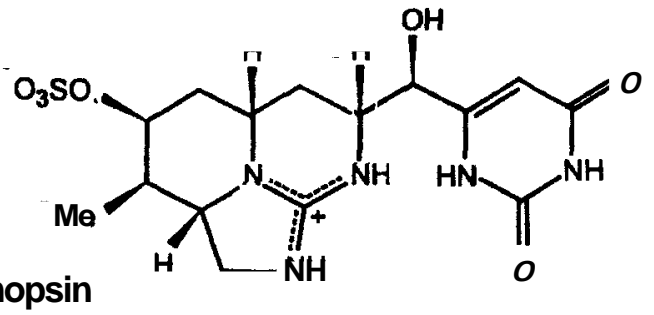

MW 415; $\mathrm{C}_{15} \mathrm{H}_{21} \mathrm{~N}_{5} \mathrm{O}_{7} \mathrm{~S}$

Figure 2. Structure of the most common hepatotoxins produced by cyanobacteria (in Sivonen and Jones, 1999). Estructura de las hepatotoxinas más comunes producidas por cianobacterias (en Sivonen and Jones, 1999)

Cyanotoxins are usually found inside cells, being degraded very slowly there (Sivonen, 1990, Rapala et al., 1997, Orr \& Jones, 1998). Even cyanobacteria scums that accumulate and dry on lake shores may retain high levels of micro- cystins for a few months (Jones et al., 1995). Animal intoxication may occur either by direct ingestion of live cells or by drinking contaminated water after the bloom collapses and toxins are released from cells. 
In Portugal, the main cyanobacteria toxins are microcystins (Vasconcelos et al., 1993, 1995, 1996), although PSP toxins have been recently described (Pereira et al., 2000, Ferreira et al., 2001). Toxic cyanobacteria occur not only in natural systems but also in waste water treatment plants (Vasconcelos \& Pereira, 2001). Microcystin-LR is the dominant toxin in blooms and in isolated strains, although MCYST-RR and MCYST-YR also occur (Vasconcelos et al., 1995, 1996).

\section{CYANOTOXINS AND EFFECTS ON AQUATIC COMMUNITIES}

Aquatic organisms from bacteria to fish may be affected by toxic cyanobacteria but also terrestrial animals such as mammals and birds may suffer from exposition to toxic cyanobacteria.

\section{Bacteria and fungi}

After the collapse of a cyanobacteria bloom, decomposition of dead cells may provide an important amount of organic matter to bacteria and fungi. Whenever toxicity occurs, it might affect more some species than others, leading to an unbalanced development of those communities. Welch (1962) studied the toxic metabolites of the cyanobacterium Lyngbya majuscula, responsible for severe human dermatitis. $\mathrm{He}$ showed that these toxins inhibited the development of fungi such as Penicillium, Candida albicans and Cryptococcus neoformans. On the other hand, Moikeha \& Chu (1971) showed that extracts of the same cyanobacterium were not toxic to Candida krusei, Penicillium notatum or P. chrysogenum. These authors reported extracts of $L$. majuscula inhibited the growth of certain bacteria species, such as Bacillus cereus, Mycobacterium smegmatis, M. phley, M. balnei, Gaffkya tetragena, Sarcina lutea and Staphylococcus aureus.

Tests performed with the freshwater cyanobacterium Microcystis aeruginosa showed that this species may inhibit the growth of Candida sp. and of some bacteria such as Escherichia, Shigella and Salmonella (Grigor'yeva et al., 1977). Grabow et al. (1982) showed that extracts of $M$. aeruginosa stimulate the growth of Escherichia coli and Streptococcus faecalis at concentrations that cause cytolythic effects on mammal cells or even lethal toxicity in mice.

More recently, Foxall \& Sasner (1988) showed that extracts of $M$. aeruginosa or pure MCYST-LR were non-toxic to $B$. subtilis, Staphylococcus aureus, E. coli or Pseudomonas hydrophila. This might be related to the fact that MCYST are potent inhibitors of protein phosphatases of eukariots (Mackintosh et al., 1990). These data are in accordance with works that show that aquatic bacteria are able to degrade cyanotoxins. Several authors found degradative bacteria in water, sediment or effluents (Jones et al., 1994, Lam et al., 1995, Rapala et al., 1997. Lahti et al., 1997).

These facts suggest certain bacteria species may take advantage of their resistance to cyanobacteria toxins.

\section{Phytoplankton}

In aquatic systems subjected to cyanobacteria blooms the phytoplankton groups other than cyanobacteria usually disappear or only attain very low densities. This leads us to the suspicion that cyanobacteria might inhibit other phytoplankton species by their release of chemical compounds to the water. Vance (1965) proved that $M$. aeruginosa was toxic to four algae species. Keating (1978) showed that filtrate from cyanobacteria cultures provoked the inhibition of diatom growth. Infante \& Abella (1985) concluded that Oscillatoria inhibited the reproduction of Cryptomonas.

Despite the scarcity of conclusive work in this field, we propose that the release of toxic compounds by cyanobacteria may be one mechanism responsible for the dominance of this group over other phytoplankton. Nevertheless, other factors may be important as well, such as the ability of cyanobacteria to fix nitrogen, to regulate their 
position in the water column and to form colonies or flakes giving them some protection against ingestion by zooplankton.

\section{Zooplankton}

The decrease of zooplankton abundance in water bodies with toxic cyanobacteria was the first observation taht lead to the hypothesis that the latter may produce toxins with deleterious effects on zooplankton (Stangenberg, 1968, Gentile, 1971, Infante \& Riehl, 1984).

Moikeha \& Chu (1971) showed that extracts of L. majuscula acted very fast to provoke the lysis of the protozoan Tetrahymena pyriformis. On the other hand, Grabow et al. (1982) using the same protozoan species showed that toxins produced by $M$. aeruginosa did not change significantly the protozoan's mobility, morphology or viability. The protozoan Paramecium caudatum, by contrast reacted very differently to the toxins of several cyanobacteria species tested. Thus, while Nostoc linckia did not cause any changes at all in the protozoan, the toxins of Gloeotrichia echinulata and of Fisherella epiphytica were lethal (Ransom et al., 1978).

Rotifers show a different response to toxins relative to other zooplankton groups, with some species being able to utilise cyanobacteria. Starkweather (1981) showed that Brachionus calicyflorus could ingest filaments of Anabaena, albeit at lower rates when compared to the control food. Nevertheless, the rotifers were able to attain sexual maturation and reproduction on a diet based on the cyanobacterium. On the other hand, Fulton \& Paerl (1987) found that during blooms of M. Aeruginosa, rotifers were usually at high density. Brachionus calicyflorus used $M$. aeruginosa in unicellular or colonial forms and attained reproduction (Fulton \& Paerl, 1987). Snell, in contrast, (1980) showed that Asplanchna girodi was sensitive to toxins of Anabaena flos-aquae and L. majuscula.

Cladocerans seem to be affected by cyanobacteria as suggested by a correlation between cladoceran body size and cyanobacteria abundance.
Stangenberg (1968) showed that extracts of $M$. aeruginosa were toxic to Daphnia longispina and to Eucypris virens. Arnold (1971) tested seven species of cyanobacteria as food for $D$. pulex showing that toxicity is species-dependent. De Bernardi et al. (1981) showed that three species of Daphnia could feed and reproduce on $M$. aeruginosa if provided in a non-colonial form. Infante \& Riehl (1984) showed that the density of cladocerans was not significantly affected during blooms of $M$. aeruginosa. Lampert (1981) also stated that while Synechococcus led to some growth of $D$. pulicaria, Aphanizomenon flosaquae and $M$. aeruginosa were not adequate. Different cyanobacteria strains producing different toxin profiles may explain these contradictory results.

Cladoceran body size may be responsible for the different reaction of cladocerans to cyanobacteria (Porter \& McDonough, 1984). Smaller cladocerans presented lower rejection and respiration rates than large animals. Vasconcelos (1990) showed that non-toxic strains of Microcystis aeruginosa used as food source for Daphnia longispina, Ceriodaphnia pulchella and Simocephalus vetulus caused total mortality to Daphnia in four days while the other two species survived longer. A toxic strain of the same cyanobacteria species produced total lethality of the three cladocerans in two days (Vasconcelos, 1990).

Recent work shows that four species of zooplankton differ in their sensitivity to hepatotoxins by two orders of magnitude (De Mott et al., 1991). Jungmann \& Benndorf (1994) also showed that Daphnia was sensitive to dissolved microcystins, although at very high concentrations, not commonly found in nature. Nevertheless, these authors used dissolved microcystin and not the whole cyanobacteria cells.

Nogueira (1999) showed that strains containing microcystins were acutely toxic to Daphnia at concentrations around $10^{5}$ cells/ml (Fig. 3). Nonmicrocystin strains caused mortality in Daphnia with LT, around 5 to 6 days (Fig. 4) (Nogueira, 1999). These data indicate that other compounds apart from microcystins may be involved in zooplankton dynamics. 


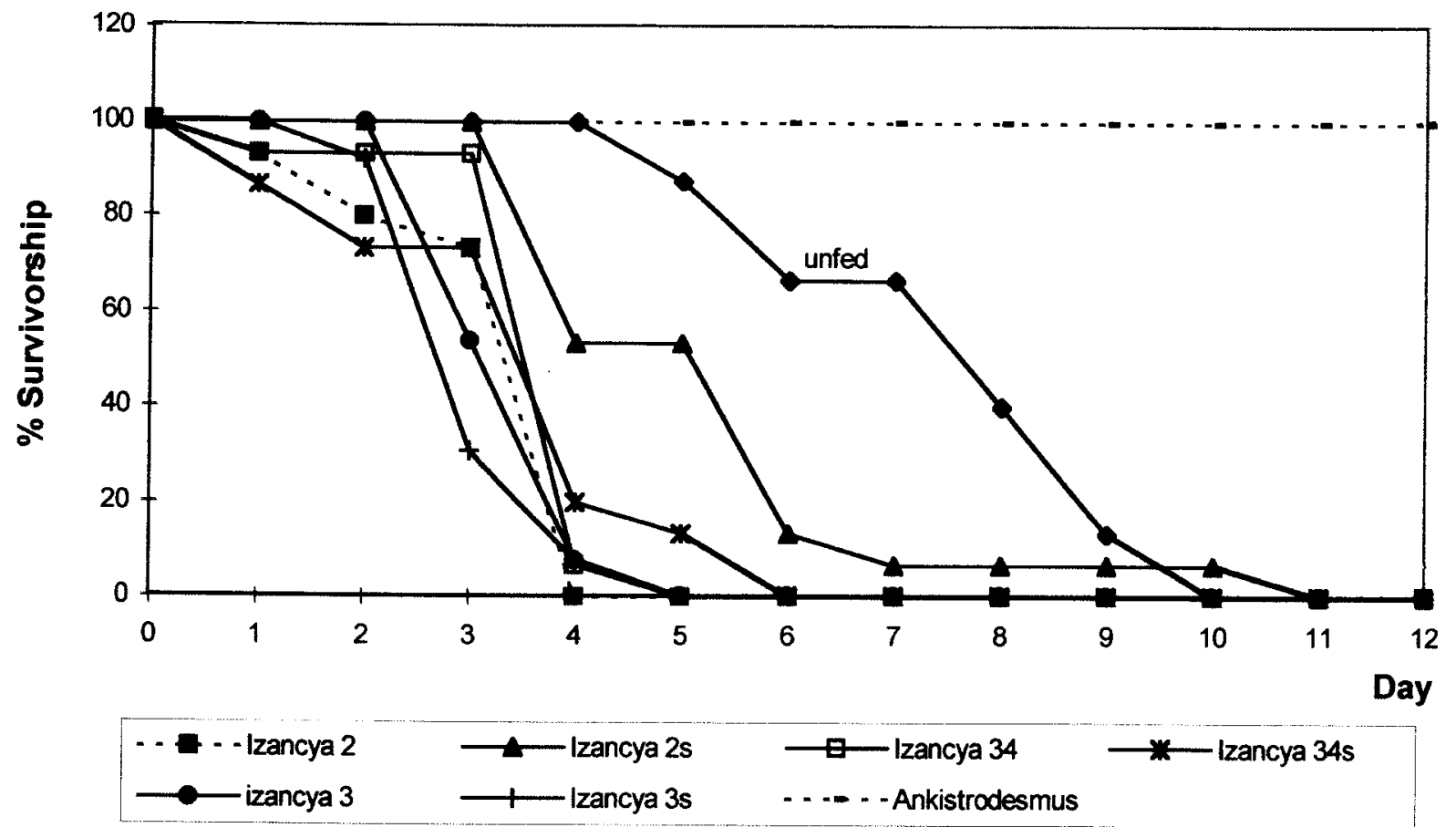

Figure 3. Effect of Microcystis strains producers of microcystins on the survivorship of Daphnia pulex . Cladocerans were fed around $10^{5}$ cells $/ \mathrm{ml}$ of intact cells and also sonicated cells (s) of different strains of Microcystis (from Nogueira, 2000). Efecto de las microcistinas producidas por la ruptura de Microcystis en la supervivencia de Daphnia pulex. Los cladóceros fueros alimentados con cerca de $10^{5}$ células $/ m l$ de células intactas y productos de células de Microcystis fragmentadas por sonicación (dr Nogueira, 2000).

In an experiment using toxic and non-toxic strains of $M$. aeruginosa as food for the copepod Acanthocyclops robustus, Vasconcelos (1990) showed that the copepod could use both strains although no reproduction was achieved.

Despite the large number of cyanobacteria strains used in experiments, we may conclude that biotoxins and other metabolites can inhibit zooplankton populations during blooms.

\section{Other invertebrates}

The impact of cyanobacteria on aquatic macroinvertebrates has not been studied very intensively. Eriksson et al. (1989) showed that the freshwater mussel Anodonta cygnea may accumulate high levels of microcystins from Oscillatoria agardhii without suffering adverse effects. Lindholm et al. (1989) also described the accumulation of hepatotoxic peptides in Anodonta from an $O$. agardhii lake bloom. On the other hand, Falconer et al. (1992) studied the marine mussel - M. edulis - proving that they could accumulate nodularins during blooms of Nodularia in an Australian estuary.

The accumulation of microcystins in invertebrates such as the crayfish Procambarus clarkii or the mussel Mytilus galloprovincialis seems to be quite fast (Vasconcelos, 1995, Amorim \& Vasconcelos, 1999, Vasconcelos et al., 2001).

Mytilus galloprovincialis are quite resistant to microcystins. These molluscs are able to exclusively feed on a toxic strain of $M$. aeruginosa for a month with a low mortality rate - 6\% (Vasconcelos 1995). The mussels may accumulate $52 \%$ of the total toxin provided in less than 2 hours, using a cell density of $10^{5}$ cells $/ \mathrm{ml}$ which is a density commonly found in aquatic systems (Vasconcelos, 1995). Nevertheless, the depura- 


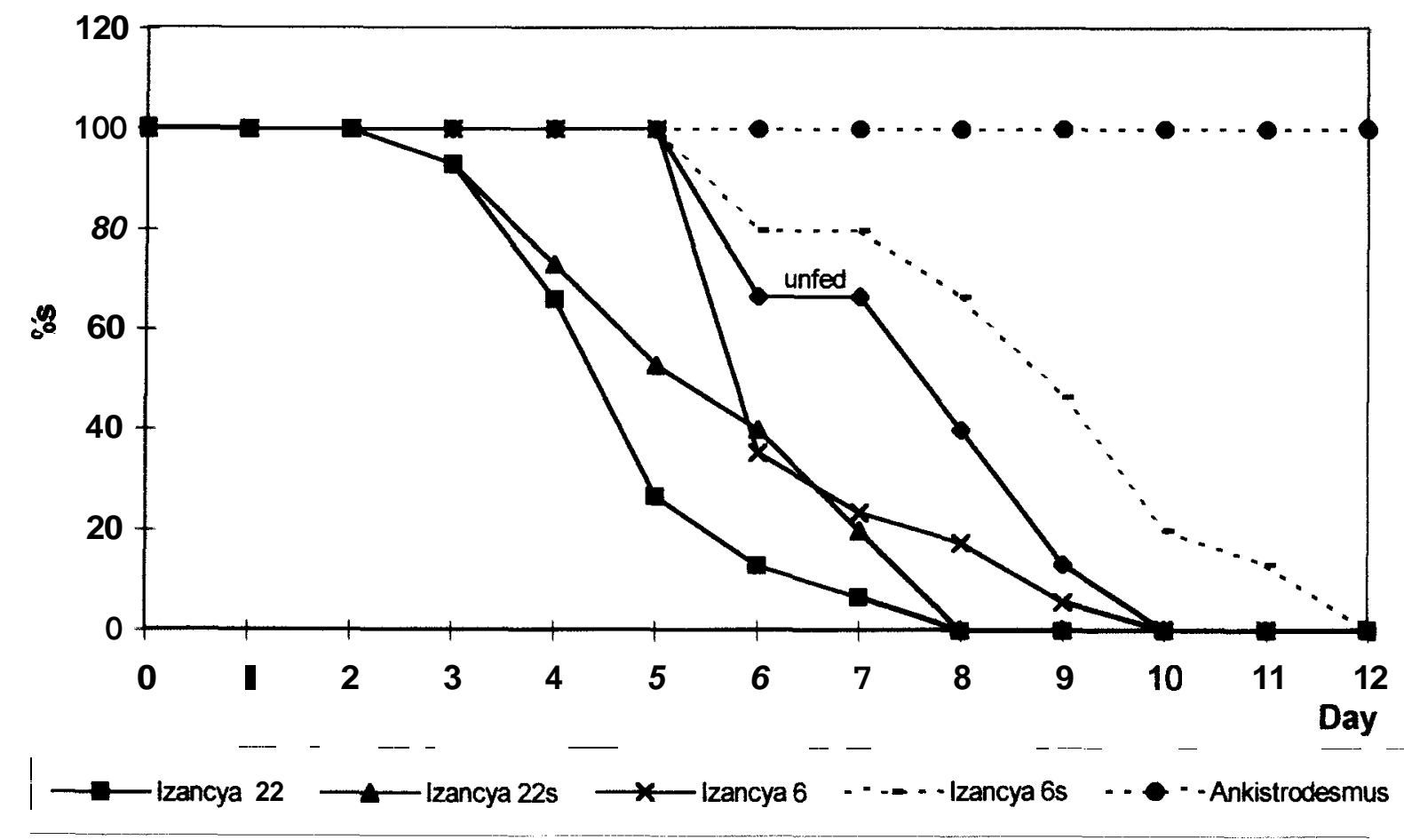

Figure 4. Effect of Microcystis strains (non-producers of microcystins) on the survivorship of Daphnia pulex. Cladocerans were fed around $10^{5} \mathrm{cells} / \mathrm{ml}$ of intact cells and also sonicated cells (s) of different strains of Microcystis. (from Nogueira, 2000). Efecto de los productos dr la ruptura de Microcystis no productoras de microcistinas en la supervivencia de Daphnia pulex. Los cladóceros fueros alimentados con cerca de $10^{5}$ células/ml de células intactas y productos de células de Microcystis fragmentadas por sonicación (de Nogueira, 2000).

tion of the toxins is very slow. Mussels contaminated with $10.7 \mathrm{mg}$ MCYST/g still had $2.5 \mathrm{mg}$ MYST/g two weeks after depuration started (Amorim \& Vasconcelos, 1999).

Crayfish are also quite resistant to toxic cyanobacteria. Larvae exposed to $3,3 \times 10^{7}$ cells $/ \mathrm{ml}$ of a toxic $M$. aeruginosa strain survived for a 72 hour period with a maximum mortality of 15\% (Vasconcelos et al., 2001). Juvenile crayfish fed on $M$. aeruginosa strains during an 8week period showed higher mortality rates if fed a strain that does not produce microcystin compared with a microcystin-producer strain (Vasconcelos et al., 2001). Crayfish also bioaccumulate microcystins at a mg/g level (Fig. 5).

\section{Fish}

The impact of cyanobacteria on fish populations is not only due to the toxins that they release but also to anoxia and the release of compounds during and after bloom collapse (Barica 1978, Ayles et al., 1986). Nevertheless, Shelubsky (1951) proved that fish deaths occurred in the presence of a toxic strain of $M$. aeruginosa with and without oxygen supply, indicating that toxins were also involved in the fish kills.

Sawyer et al. (1968) showed that the toxins of Aphanizomenon pas-aquae killed several fish species such as Catostomus commersoni, Lepomis gibbosus and Lebistes reticulatus. 


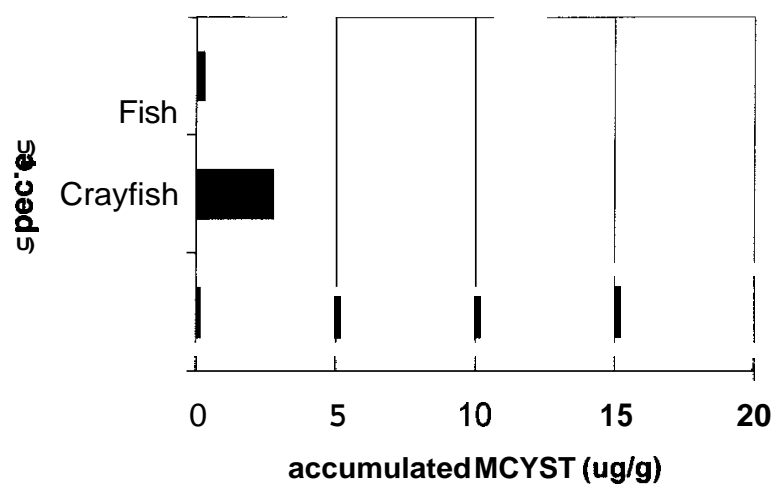

Figure 5. Average levels of microcystins (mg/g) accumulated in mussels, crayfish and fish species (in Vasconcelos, 1999). Niveles medios de rnicrocistinas ( $\mathrm{mg} / \mathrm{g}$ ) acumuladas en mejillones, cangrejos y peces (en Vasconcelos, 1999).

Gentile \& Maloney (1969) also found toxicity associated with Ay. flos-aquae cultures to Notemigonus crysleucas, Fundulus heteroclitus and Cyprinodun variegatum.

Carmichael et al. (1975) showed that Anabaena jlos-aquae was toxic to Carassius auratus when administered orally or intraperitoneally. On the other hand, if the animals were only immersed in the toxic water they did not die, meaning that the toxins were not readily absorbed through the gills.

Tencalla et al. (1994) proved that microcystins administered orally to fish caused massive hepatic necrosis followed by death. However, if fish were only immersed in contaminated water, no deaths occurred.

Age may also be an important factor. Oberemm et al. (1997) showed that microcystins may affect the development of fish embryos. On the other hand, the apparently low oral toxicity of fish may lead to the bioaccumulation of toxins. Vasconcelos (1999) showed that wild fish species such as carp, barbel or mullet might accumulate microcystins in the muscle (Fig. 6). Levels of microcystins reached $250 \mathrm{ng} / \mathrm{g}$ in the edible parts, while in the viscera values may be ten to hundred fold higher. The amount of toxins detected in flesh are not very significant in terms of human health except for fishermen populations with a diet based on fish.

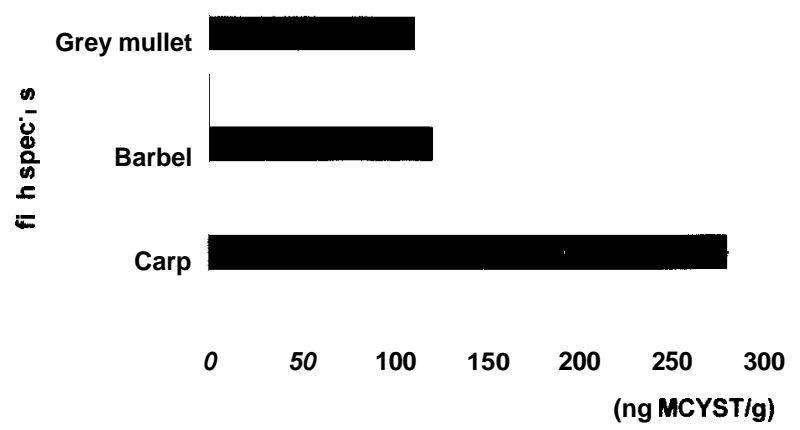

Figure 6. Levels of microcystins $(\mathrm{mg} / \mathrm{g})$ accumulated in different fish species (in Vasconcelos, 1999). Niveles de microcistinas ( $\mathrm{mg} / \mathrm{g}$ ) acumuladas en diferentes especies de peces (en Vasconcelos, 1999).

\section{Birds}

The occurrence of high mortality of birds associated with the occurrence of cyanobacteria blooms is a fact referred to by many authors (Bossenmaier et al., 1954, Ingram \& Prescott, 1954, Davidson 1959, Senior 1960). However, botulism in birds frequently coincides with the occurrence of toxic cyanobacteria malung it difficult to distinguish the causes of deaths (Bossenmaier et al., 1954).

Gorham (1960) described the lethal effects of a strain of $M$. aeruginusa administered orally to chickens but stated that the same strain was non toxic to ducks. Konst et al. (1965) testing the same cyanobacteria species verified that ducks were completely resistant to oral doses that were lethal to mice and sheep. However, this apparent resistance of ducks to cyanobacterial toxins cannot be generalized to all types of toxins. For instance, in a work done with a toxic Anabaena \$us-aquae, Carmichael \& Gorham (1977) concluded that ducks and pheasants were more sensitive to the toxins than mice were. McBarron et al. (1975), by contrast, showed that toxins of $A$. circinalis administered orally were lethal to mice and sheep but not to chicken. Carmichael \& Gorham (1978) proposed that ducks are more sensitive than pheasants to Anabaena flos-aquae toxins because of the different sensitivity to the 
toxins of neuromuscular junctions in both species.

\section{Mammals}

The association between cattle mortality and toxic cyanobacteria was first described by Francis (1878), but many other reports followed (McLeod \& Bondar, 1952, Davidson, 1959, Siegelman et al., 1984).Toxic Microcystis may cause symptoms such as prostration, loss of equilibrium, muscle trembling (MacDonald 1960), periods of hyper excitability followed by apatia and weakness (Konst et al., 1965), diarrhoea (Dillemberg \& Dehnel, 1960, Aziz, 1974) and, finally, death. On the other hand, toxic Anabaena flos-aquae and Aphanizomenon flos-aquae may cause muscle paralysis and respiratory arrest in a short period of time (McLeod \& Bondar, 1952, Carmichael et al., 1975). Beasley et al. (1983) reported the death of 10 pigs after ingestion of water contaminated with a toxic $A$. spiroides bloom.

\section{Human intoxication}

The occurrence of toxic cyanobacteria blooms was first associated to human intoxication in the early 1930's (Tisdale, 1933, Heise \& Milwaukee, 1949). The main routes for cyanobacteria toxins in humans are ingestion (toxins in water, contaminated food), inhalation (water sports, bathing in contaminated waters), skin contact (recreation, bathing) and intravenous (dialysis). The only reported lethal human intoxication was due to the use of water contaminated with cyanotoxins in a dialysis clinic in Caruaru, Brazil (Jochimsen et al., 1999). Although maybe not the most common route for intoxication in humans, it is certainly the most tragic.

\section{CONCLUSIONS}

The toxicity of cyanobacteria, formerly associated to mammal bioassays should be studied taking into account other bioassays. This approach is necessary for a better understanding of the ecological role of cyanobacteria metabolites. Although the most common biotoxins - hepatotoxins, neurotoxins and irritants - may cause adverse effects to procariont and eucariont populations, other, less common, compounds may also have an important role. Although biotoxins only affect organisms when the cyanobacteria cell lyse, other bioactive compounds may be excreted to the water. This chemical signalling is much more effective and with more pronounced effects in aquatic communities.

The long-term evolution of cyanobacteria have enabled them to develop an important diversity not only in terms of habitats but also in terms of metabolic products produced by them. The cooccurrence of toxic compounds to mammals, and anticarcinogenic and carcinogenic compounds in one single organism is a source for numerous future studies on the bioactivity of metabolites from cyanobacteria.

\section{ACKNOWLEDGEMENTS}

The author acknowledges M. Rosa Miracle and Eduardo Vicente of Valencia University for the invitation to present this paper at the "II Congreso Ibérico de Limnología” (Valencia 2000).

\section{REFERENCES}

AMORIM, A. \& V.M. VASCONCELOS, 1999. Dynamics of microcystins in the mussel Mytilus galloprovincialis. Toxicon, 37: 1041-1052.

ARNOLD, D.E. 1971. Ingestion, assimilation, survival and reproduction by Daphnia pulex fed seven species of blue-green algae. Limnol. Oceanogr., $16: 906-919$.

AZIZ, K.M.S. 1974. Diarrhoea toxin obtained from a water bloom-producing species, Microcystis aeruginosa Kutzing. Science, 183: 1206-1207.

AYLES, G.B., J.G.I. LARK, J. BARICA \& H. KLING. 1986. Seasonal mortality in rainbow trout (Salmo gairdneri) planted in small eutrophic lakes of Central Canada. J. Fish. Res. Board Can., 37: 647-655. 
BARICA, J. 1978. Collapses of Aphanizomenon flosaquae blooms resulting in massive fish kills in eutrophic lakes. Verh.Internat. Verein.Limnol., 20: 208-213.

BEASLEY, V.R., R.W. COPPOCK, J. SIMON, R. ELY, W.B. BUCK \& R.A CORLEY. 1983. Apparent blue-green algal poisoning in swine subsequent to ingestion of a bloom dominated by Anabena spiroides. J. Amer. Vet. Med. Assoc., 182:413-414.

BOSSENMAIER, E., T.A. OLSON, M.E. RUEGER \& W.H. MARSHALL. 1954. Some field and laboratory aspects of duck sickness at White water Lake, Manitoba. Nineteenth North American Wildlife Conference: 163-175.

CARMICHAEL W.W. \& P.R. GORHAM. 1977. Factors influencing the toxicity and animal susceptibility of Anabaena flos-aquae (Cyanophyta) blooms. J. Phycol., 13: 97-101.

CARMICHAEL W.W. \& P.R. GORHAM. 1978. Anatoxins from clones of Anabaenaflos-aquae isolated from lakes of western Canada. Mitt. Internat. Verein.Limnol., 21 :285-295.

CARMICHAEL, W. W., D.F. BIGGS \& P.R. GORHAM. 1975. Toxicology and pharmacological action of Anabaena flos-aquae toxin. Science, 187: 542-544.

DAVIDSON, F.F. 1959. Poisoning of wild and domestic animals by a toxic water bloom of Nostoc rivulare Kutz. J.Amer. Water Works Assoc., 51: 1277 1287.

DE BERNARDI, R., G. GIUSSANI, \& PEDRETTI, 1981. The significance of blue-green algae as food for filterfeeding zooplankton: experimental studies on Daphnia spp. fed by Microcystis aeruginosa. Verh. Internat. Verein. Limnol., 21: 477-483.

De MOTT, W.W., Q. ZHANG \& W.W. CARMICHAEL, 1991. Effects of toxic cyanobacteria and purified toxins on the survival and feeding of a copepod and three species of Daphnia. Limnol. Oceanog., 36: 1346-1357.

DILLENBERG H.O. \& M.K. DENHEL 1960. Toxic waterbloom in Saskatchewan, 1959. Can. Med. Assoc. J., 83: 1151-1154.

ERIKSSON, J.E., J.A. MERILUOTO \& T. LINDHOLM, 1989. Accumulation of peptide toxin from the cyanobacterium Oscillatoria agardhii in the freshwater mussel Anodonta cygnea. Hydrobiologia, 183: 211-216.

FALCONER I.R. \& S.K. YEUNG, 1993. Cytoskeletal changes in hepatocytes induced by Microcystis tox- ins and their relation to hyperphosphorylation of cell proteins. Chem. Biol. Interact., 81: 181-196.

FALCONER, I.R., A.M BERESFORD \& M.T.C. RUNNEGAR 1983. Evidence of liver damage by toxin from a bloom of the blue-green alga Microcystis aeruginosa. Med. J. Aust., 1: 511-514.

FALCONER, I.R., A. CHOICE \& W HOSJA, 1992. Toxicity of the edible mussel Mytilus edulis) growing naturally in an estuary during a water-bloom of the blue-green alga Nodularia spumigena. J. Env. Toxicol. Water Quality, 7: 119-123.

FERREIRA, F.M.B., J.M.F. SOLER, M.L.FIDALGO \& P.FERNANDEZ-VILA. 2001. PSP toxins from Aphanizomenon flos-aquae (cyanobacteria) collected in the Crestuma-Lever reservoir (Douro River, Portugal). Toxicon., 39: 757-761.

FOXALL, T.L. \& J.J. SASNER, 1988. Effect of a hepatic toxin from the cyanophyte Microcystis aeruginosa. In The Water Environment. Algal Toxins and Health W.W. Carmichael (ed). Plennun Press, New York.

FRANCIS, G. 1878. Poisonous Australian lake. Nature, 18: 11-12.

FUJIKI H. \& M. SUGANUMA, 1993. Tumor promotion by inhibitors of protein phosphatases 1 and $2 \mathrm{~A}$ : the okadaic acid class of compounds. Adv. Cancer Res., 61: 143-194.

FULTON R.S. \& H.W. PAERL 1987. Toxic and inhibitory effects of the blue-green alga Microcystis aeruginosa on herbivorous zooplankton. J. Plankton Research, 9: 837-855.

GENTILE, J.H. 1971. Blue-green and green algal toxins. In. Microbial Toxins. Vol. VII. Algal andfungus toxins. (Ajl, S.J., A. Cieglen, S. Kadis, T.C. Montie \& E.G. Weinbaum eds.): 27-66. Academic Press, NY and London.

GENTILE J.H \& T.E. MALONEY 1969. Toxicity and environmental requirements of a strain of Aphanizomenon flos-aquae (L.) Ralfs. Can. J. Microbiol., 15: 165-173.

GORHAM, P.R. 1960. Toxic waterblooms of bluegreen algae. Can J. Vet. J., 1: 235-245.

GRABOW, W.O., W.C. DU RANDT PROZESKY \& W.E. SCOTT 1982. Microcystis aeruginosa toxin: cell culture toxicity, hemolysis and mutagenicity assays. Applied and Environmental Microbiology., 43: 1425-1433.

GRIGOR'YEVA, L. V., YU.A. KIRPENKO, V.M. ORLOVSKIY \& V.V. STANKEVICH, 1977. Antimicrobial action of toxic metabolites of some blue-green algae. Gidrobiol. Zh., 13: 57-62. 
HAWKINS, P.R., N.R. CHANDRASENA, G.J. JONES, A.R. HUMPAGE \& I.R. FALCONER 1997. Isolation and toxicity of Cylindrospermopsis raciborskii from an ornamental lake. Toxicon., 35: 341-346.

HAWKINS, P.R., M.T.C. RUNNEGAR, A.R.B. JACKSON \& I.R. FALCONER 1985. Severe hepatotoxicity by the tropical cyanobacterium (bluegreen algae) Cylindrospermopsis racihorskii (Woloszynska) Seenaya and Subba Raju isolated from a domestic water supplu reservoir. Appl. Environ. Microbiol., 50: 1292-1295.

HEISE H.A. AND M.D. MILWAUKEE 1949. Symptoms of hay fever caused by algae. $J$. of Allergy, 20: 383-385.

INFANTE A. AND S.E.B. ABELLA 1985. Inhibition of Duphnia by Oscillatoria in lake Washington. Limnol. Oceanogr., 30: 1046-1052.

INFANTE A. \& W. RIEHL 1984. The effect of Cyanophyta upon zooplankton in a eutrophic tropical lake (lake Valencia, Venezuela). Hydrohiologiu, 113: 293-298.

INGRAM W.M. \& G.W. PRESCOTT 1954. Toxic freshwater algae. Am. Midl. Nut., 52: 75-87.

JOCHIMSEN, E.M., W.W. CARMICHAEL, J. AN , D.M. CARDO, S.T. COOKSON, C.E.M. HOLMES, M.B. ANTUNES, D.A. FILHO, T.M. LYRA, V.S.T. BARRETO, S.M.F.O. AZEVEDO \& W.R. JARVIS 1998. Liver failure and death after exposure to microcystins at a haemodialysis center in Brazil. New Engl. J. Med., 338: 873-878.

JONES, G.J., S.I. BLACKBURN \& N.S. PARKER, 1994. A toxic bloom of Nodularia spumigena Mertens in Orielton Lagoon, Tasmania. Australian J. Mar. Freshwat. Res., 45: 787-800.

JONES, G.J., I.F. FALCONER, \& R.M. WILKINS, 1995. Persistence of cycic peptide toxins in dried cyanobacterial crusts from Lake Mokoan, Australia. Environ. Toxicol. Water Quality, 10: 19-24.

JUNGMANN, D. \& J. BENNDORF, 1994. Toxicity to Duphnia of a compound extracted from laboratory and natural Microcystis spp. and the role of microcystins. Freshwat. Biol., 32: 13-20.

KEATING, K.I. 1978. Blue-green algal inhibition of diatoms growth: transition from mesotrophic to eutrophic community structure. Science, 199:971-973.

KONST, H., P.D. MCKERCHER, P.R. GORHAM, A. ROBERTSON \& J. HOWELL 1965. Symptoms and pathology produced by toxic Microcystis aeruginosa NRC-1 in laboratory and domestic animals. Can. J. Comp. Med. Vet. Sci., 29: 221-228.
KUIPER-GOODMAN T., I. FALCONER \& J. FITZGERALD 1999. Human Health Aspects. In: Toxic Cyunohacteria in Water. I. Chorus \& J. Bartram (eds.): 113-154, Who and E \& FN Spon, London.

LAHTI, K., M.R. NIEMI, J. RAPALA \& K. SIVONEN. 1997. Biodegradation of cyanobacterial hepatotoxins- characterization of toxin degrading bacteria. Proceedings of the VII International Conference oh Harmfull Algae.

LAM, A.K.-Y., P.M. FEDORAK \& E.E. PREPAS 1995. Biotransfromation of the cyanobacterial hepatotoxin microcystin-LR, as determined by HPLC and protein phosphatase bioassay. Env, Sci. Technol., 29: 242-246.

LAMPERT, W. 1981. Toxicity of the blue-green Microcystis aeruginosu: effective defense mechanism against grazing pressure by Daphnia. Verh. Internat. Verein. Limnol., 21 : 1436-1440.

LINDHOLM, T., J.E. REISSON \& J.A.O. MERILUOTO, 1989. Toxic cyanobacteria and water quality problems - examples from a eutrophic lake on Aland, South West Finland. WaterRes., 23:481-486.

MACKINTOSH, C., K.A. BEATTIE, S. KLUMP, P. COHEN \& G.A. CODD 1990. Cyanobacterial microcystin-LR is a potent and specific inhibitor of protein phosphatases 1 and 2A from both mammal and higher plants. Fed. Eur. Biochem. Soc. Lett., 264: 187-192.

MCBARRON, E.J., R.I. WALKER, I. GARDENER \& K.H. WALKER 1975. Toxicity to livestock of the blue-green alga Anabaena circinalis. Aust. Vet. J., 51: 587-588.

MCDONALD, D.W. 1960. Algal poisoning in beef cattle. Can. Vet.J., 1: 108-110.

MCLEOD J. A. \& G.F. BONDAR 1952. A case of suspected algal poisoning in Manitoba. Can. J. Pub. Health., 43: 347-350.

MOIKEHA, S.N. \& G.W. CHU 1971. Dermatitis-producing alga Lyngbya majuscula Gomont in Hawaii. II. Biological properties of the toxin factor. $J$. Phycol., 7: 8-13.

NOGUEIRA, I. 1999. Efeitos ecotoxicológicos de Microcystis aeruginosa em Daphnia pulex. MSc thesis,Porto University (in Portuguese. $64 \mathrm{pp}$ ).

OBEREMM, A., J. FASTNER, \& C. STEINBERG., 1997. Effects of microcystin-LR and cyanobacterial crude extracts on embryo-larval development of zebrafish (Danio rerio) Wat. Res., 31: 2918-2921.

ORR P.T. \& G.J. JONES, 1998. Relationship between microcystin production and cell division rates in nitrogen-limited Microcystis aeruginosa culturres. Limnol. Oceanogr., 43. 
PEREIRA P., O. HIDEYUKI, D. ANDRINOLO, S. FRANCA, F. ARAUJO, N. LAGOS \& Y. OSHIMA, 2000. Paralytic shellfish toxins in the freshwater cyanobacterium Aphanizomenon flosaquae, isolated from Montargil reservoir, Portugal, Toxicon, 38:1689-1702.

PORTER K.G. \& R. MCDONOUGH 1984. The energetic cost of response to blue-green algal filaments by cladocerans. Limnol. Ocaenogr., 29: 365-369.

RANSOM, R.E., T.A. NEVAD \& P.G. MEIER 1978. Acute toxicity of the blue-green algae to the protozoan Paramecium caudatum. J. Phycol., 14: 114-116.

RAPALA, J., K., SIVONEN, C. LYRA \& S.I. NIEMELA., 1997. Variation of microcystins, cyanobacterial hepatotoxins in Anabaena spp. as a function of growth stimuli. App. Environ. Microbiol., 64: 2206-2212.

RUNNEGAR M.T C., S.M. KONG \& N. BERNDT., 1993. Protein phosphatase inhibition and in vivo hepatotoxicity of microcystins. Am. J. Physiol., 265: G224-G230.

RUNNEGAR M.T.C., S.M., KONG, Y.Z. ZHONG, J.L. GE \& S.C.LU 1994. Inhibition of reduced glutathione in the toxicity of a novel alkaloid cylindrospermopsin in cultured rat hepatocytes. Biochem. Biophys. Res. Commun., 201: 235-241.

SAWYER, P.J., J.H.GENTILE \& J.J. SASNER. 1968. Demonstration of a toxin from Aphanizomenon flos-aquae (L.) Ralfs. Can. J. Microbiol., 14: 1199-1204.

SENIOR, V.E. 1960. Algal poisoning in Saskatchewan. Can. J. Comp. Med., 24: 36-40.

SHELUBSKY, M. 1951. Observations on the properties of a toxin produced by Microcystis. Verh. Internat. Verein. Limnol., 11: 363-366.

SIEGELMAN, H.W., W.H. ADAMS, R.D. STONER \& D.N. SLATKIN 1984. Toxins of Microcystis aeruginosa and their haematological and histopathological effects. American Chemical Society Symposium on Seafood toxins, 407-4 13.

SIVONEN, K.1990. Effects of light, temperature, nitrate, orthophosphate and bacteria on growth of and hepatotoxin production by Oscillatoria ugardhii strains. App. Environ. Microbiol., 56 :2658-2666.

SIVONEN K. \& G. JONES 1999. Cyanobacterial toxins. In Toxic Cyunobacteria in Water: (I. Chorus \& J. Bartram, eds.): 41-111, Who and E \& FN Spon, London.

SNELL, T.W. 1980. Blue-green algae and selection in rotifer populations. Oecologia, 46: 343-346.
STANGENBERG, M. 1968. Toxic effects of Microcystis aeruginosu Kg. extracts on Daphnia longispina O.F. Muller and Eucypris virens Jurine. Hydrobiologia, 32: 81-87.

STARKWEATHER, P.L. 1981. Trophic relationships between the rotifer Brachionus calyciflorus and the blue-green algae Anabaena flos-aquae. Verh. Internat. Verein Limnol, $21: 1507-1514$.

TENCALLA, F.G., D.R. DIETRICH \& C. SCHLATTER 1994. Toxicity of Microcystis aeruginosa peptide toxin to yearling rainbow trout (Oncorhynchus mykiss). Aquat. Toxicol., 30 :215224.

TERAO, K., S. OHMORI, K., IGARASHI, I. OHTANI, M. WATANABE, K.-I. HARADA, E. ITO \& M. WATANABE, 1994. Electron microscopic studies on experimental poisoning in mice induced by cylindrospermopsin isolated from bluegreen alga Umezakia natans. Toxicon., 32: 833-843.

TISDALE, E.S. 1933. The 1930-1931 drough and its effects upon public water supply. Amer. J. Public Health, 21: 1203-1215.

TURNER, P.C., A.J. GAMMIE, K. HOLLINRAKE \& G.A. CODD 1990. Pneumonia associated with cyanobacteria. Br. Med. J., 300: 1440-1441.

VANCE, B.D. 1965. Sensitivity of Microcystis aeruginosa and other blue-green algae and associated bacteria to selected antibiotics. J. Phycol., 2: 125128.

VASCONCELOS, V. M., 1990. Preliminary results of a study on the impact of toxic and nontoxic cyanobacteria on some freshwater microcrustacean species. Crustaceana, 59: 316-318.

VASCONCELOS, V.M. 1995. Uptake and depuration of the peptide toxin microcystin-LR in the mussel Mytilus galloprovinciallis. Aquatic Toxicology, 32: 227-237.

VASCONCELOS, V.M. 1999. Cyanobacteria toxins in Portugal: effects on aquatic animals and risk for human health. Brazilian Journal of Medical and Biological Research, 32: 249-254.

VASCONCELOS, V.M. \& E. PEREIRA, 2001. Cyanobacteria diversity and toxicity in a Wastewater Treatment Plant (Portugal). Water Res., 35: 1354-1357.

VASCONCELOS V.M.,S. OLIVEIRA \& L.F. OLIVA TELES. 2001. Impact of a toxic and a non toxic strain of Microcystis aeruginosa in the crayfish Procambarus clarkii . Toxicon, (in press).

VASCONCELOS, V.M, W. EVANS, W.W. CARMICHAEL \& M. NAMIKOSHI, 1993. Isolation of mi- 
crocystin-LR from a Microcystis (Cyanobacteria) bloom collected in the drinking water reservoir for Porto, Portugal. J. Env. Sci. Health., 28(9): 2081-2094.

VASCONCELOS, V.M., K. SIVONEN, W.R. EVANS, W.W. CARMICHAEL \& M. NAMIKOSHI, 1995. Isolation and characterization of microcystins (heptapeptide hepatotoxins) from Portuguese strains of Microcystis aeruginosa Kutz. emed Elekin. Arch. Hydrobiol., 134: 295-305.
VASCONCELOS, V.M., K. SIVONEN, W.R. EVANS, W.W. CARMICHAEL \& M. NAMIKOSHI 1996. Hepatotoxic microcystin diversity in cyanobacterial blooms collected in Portuguese freshwaters. Water Research., 30: 2377-2384.

WELCH, A.H. 1962. Preliminary survey of fungistatic properties of marine algae. J. Bacteriol., 83: 97-99. 